University of Nebraska - Lincoln

DigitalCommons@University of Nebraska - Lincoln

Papers in Communication Studies

Communication Studies, Department of

$1-2008$

\title{
Mississippiss Social Transformation in Public Memories of the Trial against Byron de la Beckwith for the Murder of Medgar Evers
}

Kristen Hoerl

Auburn University, khoerl2@unl.edu

Follow this and additional works at: http://digitalcommons.unl.edu/commstudiespapers

Part of the Critical and Cultural Studies Commons, Gender, Race, Sexuality, and Ethnicity in Communication Commons, and the Other Communication Commons

Hoerl, Kristen, "Mississippi's Social Transformation in Public Memories of the Trial against Byron de la Beckwith for the Murder of Medgar Evers" (2008). Papers in Communication Studies. 195.

http://digitalcommons.unl.edu/commstudiespapers/195

This Article is brought to you for free and open access by the Communication Studies, Department of at DigitalCommons@University of Nebraska Lincoln. It has been accepted for inclusion in Papers in Communication Studies by an authorized administrator of DigitalCommons@University of Nebraska - Lincoln. 
Published in Western Journal of Communication 72:1 (January-March 2008), pp. 62-82;

doi: 10.1080/10570310701828966

Copyright (C 2008 Western States Communication Association; published by Routledge/Taylor \& Francis. Used by permission.

Published online March 11, 2008.

\title{
Mississippi's Social Transformation in Public Memories of the Trial against Byron de la Beckwith for the Murder of Medgar Evers
}

\author{
Kristen Hoerl \\ Department of Communication and Journalism, Auburn University, Auburn, Alabama, USA \\ Corresponding author - Kristen Hoerl, Department of Communication and Journalism, 0336 Haley, Auburn University, \\ Auburn, AL 36849-5211, USA, email hoerlke@auburn.edu
}

\begin{abstract}
In 1994, Byron de la Beckwith was convicted for the 1963 murder of civil rights activist Medgar Evers. Journalistic coverage of the trial and the 1996 docudrama Ghosts of Mississippi crafted a social values transformation myth that depicted Beckwith as the primary villain of the civil rights past and cast his conviction as a sign that racism had been cleansed from Mississippi. Popular media naturalized this myth intertextually though narrative repetition and through symbolic cues that established the film as a source of historic understanding. These cues deflected critical attention from contemporary social conditions that have maintained racial inequity and continue to prompt racially motivated hate crimes.
\end{abstract}

Keywords: Byron de la Beckwith, civil rights, Ghosts of Mississippi, hegemony, Medgar Evers, public memory, social values transformation myth

On June 12 1963, NAACP field secretary Medgar Evers was shot to death in front of his home in Jackson, Mississippi. Nine days later, police arrested avowed White supremacist Byron de la Beckwith for Evers's murder. Although prosecutors created a strong case 
against him, Beckwith was set free after two White male juries failed to reach a unanimous verdict. The outcome of these trials fit within a broader pattern of state-sanctioned violence against civil rights activists and African Americans not directly involved with the movement during the 1950s and 1960s. During these decades, state police frequently looked the other way when activists and Blacks were beaten or killed. The state's legal system also failed victims of racially motivated violence; Beckwith's trials are two examples among many cases in which all-White juries failed to convict Whites of murdering Blacks despite strong physical evidence (Nichols \& Howlett, 1992, p. A1; Nossiter, 1994/2002, p. 18). ${ }^{1}$

Thirty years after his death, Evers's ghost haunted the courts and the media. In 1994, the state returned its attention to Evers's murder and convinced a jury composed of White and Black jurists to convict Beckwith. Beckwith's conviction was remarkable; never before had so much time elapsed between a homicide and the conviction of the person responsible (Nossiter, 1994/2002, p. B18). Following Beckwith's conviction and the consequent media attention, several other cold cases of civil rights atrocities have been tried by contemporary courts. Beckwith's conviction set the precedent for these trials and motivated civil rights activists to push state attorneys' offices to pursue convictions of known suspects in civil rights murders who had not faced legal prosecution in the decades preceding the era of civil rights activism (Mayfield, 1992a, p. 3A; "Mississippi," 1990, p. 6A). Five men, some in their 80s, have been convicted for their involvement in hate crimes committed some 30 years ago. ${ }^{2}$ In June 2005, 80-year-old Edgar Ray Killen was convicted of manslaughter for his involvement in the 1964 slayings of activists George Chaney, Michael Schwerner, and Andrew Goodman (Tucker, 2005, p. 9A).

Beckwith's trial is also remarkable for its national presence both in journalistic reports and Hollywood film. Between 1989 and 2001, at least 376 articles in the nation's leading newspapers featured Beckwith. In 1996, the movie Ghosts of Mississippi recalled state district attorney Bobby DeLaughter's efforts to bring Beckwith to trial and have a jury find him guilty of Evers's death. According to the Internet Movie Database, this film earned \$13 million at the box office. In 1997, it received two Academy Award nominations, including one for James Woods's supporting role portraying Beckwith ("Academy Awards nominees," 1997, p. 3D). Because the press and Hollywood depicted Beckwith's prosecution, an analysis of Ghosts of Mississippi and news media depictions of Beckwith's trial provides a richer explanation of the processes of public memory construction in popular culture than an analysis of either newspapers or the film alone.

I argue that journalistic coverage of Beckwith's trial and Ghosts of Mississippi worked together to compose a narrative that established Beckwith's conviction as the conclusion to the civil rights struggle. In this narrative, Beckwith personified evil racism, while efforts by state prosecutors symbolized Mississippi's racial progress. These divergent character depictions helped to frame Beckwith's conviction as a sign of Mississippi's transformed race relations and the end of racial discrimination in the state. This narrative also consigned movements for racial justice to the past by deflecting attention from the structural and institutional sources of racial injustice and erasing the legacy of civil rights activism from public memory. 


\section{The Struggle for Hegemony in Public Memory}

Mainstream media attention to Beckwith's trial offered audiences resources for understanding racism's legacy in recent United States history and functioned as a resource for public memory. According to Bodnar (1992), public memory is a "body of beliefs and ideas about the past that help a public or society understand both its past, present, and by implication, its future" (p. 15). Public memory scholars have suggested that depictions of the past have rhetorical and political implications. Kammen (1991) argues that "societies ... reconstruct their pasts with the needs of contemporary culture clearly in mind-manipulating the past in order to mold the present" (p. 3). Frequently, depictions of the past mold the present by reaffirming the legitimacy of contemporary social and political relations. Commemorative texts, including memorial structures (Bodnar, 1992; Ehrenhaus, 1989; Kammen, 1991), political speeches (Browne, 1999; Dionisopolous \& Goldzwig, 1992), and films (Ehrenhaus, 2001; Madison, 1999; Owens, 2002), are frequently constructed in the interests of political leaders and mainstream political ideology.

Public memories that serve dominant political interests have implications for hegemony. Gramsci's model of hegemony $(1977,1971)$ explains how social relations are reproduced through a range of cultural practices by which the dominant power elicits consent to its leadership. While hegemony operates in virtually every sphere of life, ideological texts play a central role in its existence. As Eagleton (1991) asserts, "To win hegemony is to diffuse one's own worldview throughout the fabric of society ... equating one's own interests with the interests of society at large" (pp. 115-116). Media scholars Madison (1999) and Brinson (1995) argue that popular civil rights films have repeatedly reaffirmed White hegemony in the face of civil rights injustices that challenged the legitimacy of racist power structures. Madison (1999) argues that recent films about race, including Mississippi Burning, The Long Walk Home, and Cry Freedom, symbolically reasserted the subordination of Blacks by relegating them to the background of stories about their own struggles. Brinson (1995) contends that the 1988 Mississippi Burning communicated the myth of White superiority to resolve cultural tensions about the authority of the White power structure in the late 1980s.

Brinson and Madison persuasively argue that civil rights films reinforce the legitimacy of dominant (White) hegemony; however, public memory scholarship indicates that film's hegemonic status is contested. Representations of the past are necessarily incomplete, partial, and limited by the perspectives of those who create them (Sturken, 1997; Zelizer, 1995). Thus, they are sites of political debate and struggle between competing interest groups (Bodnar, 1992). In their analysis of the various artifacts that make up the collective memory of the Amistad Affair, Hasian and Carlson (2000) argue that the selective and partial narrative of the movie Amistad excluded historic events important to marginalized groups and discouraged audiences from discovering the multiplicity of positions regarding the Amistad case (p. 60). Elsewhere, Hasian (2001) asserts that public memories emerge out of a confluence of competing messages about the past. Hasian explains how the movie Saving Private Ryan availed itself to several competing interpretations to fit the needs of different audiences who struggled over the meaning of World War II. Based on this analysis, Hasian 
concludes that the film is an intertextual fragment that animated the polysemic and polyvalent nature of World War II memory (p. 339). The contrast between public memory scholarship that characterizes public memories as hegemonic and literature that characterizes public memories as intertextual phenomena suggests that not all media depictions of previous events equally inform public knowledge about the past. One way that we can determine which media depictions are hegemonic resources is by attending to patterns across multiple popular culture texts that give meaning to events from the past and establish their role in the present.

\section{The Intertextual Construction of Beckwith's Conviction}

Both news coverage and the film Ghosts of Mississippi characterized Beckwith's prosecution as an important civil rights memory. Collectively, the New York Times, USA Today, and the Washington Post covered the trial in 95 articles. These articles described the events leading up to Beckwith's arrest in 1990, the arguments made by attorneys prosecuting Beckwith during his trial in 1994, and the Evers family's celebration following Beckwith's conviction. These three newspapers are important sites of public memory because they have some of the largest circulation rates in the United States and often lead other newspaper coverage of national events. Taking a cue from news media framing scholarship (Gitlin, 1980; Hall, Critcher, Jefferson, Clarke, \& Roberts, 1978; Watkins, 2001) that draws attention to the ways in which news coverage systematically organizes meanings of news events through the processes of selection and omission, I address the patterns that ran across these three newspapers to ascribe meaning to Beckwith's prosecution as a sign of changing race relations in Mississippi.

I also attend to the ways that Ghosts of Mississippi extended the meaning of Beckwith's conviction for the civil rights struggle. Specifically, I explain how the film depicted Beckwith's conviction as a broader social values transformation. Describing the Social Value Model of rhetorical criticism, Rushing and Frentz (1978) argue that films and sociopolitical processes exist in "an interdependent relationship" (p. 66). Struggles between characters, verbal or physical, symbolize broader social conflicts over values that are in dialectical opposition to one another. The critic's task is to identify how tensions over values are symbolically manifested through conflicts between characters in a given film. Based on the identification of value conflicts and their symbolic enactment, the critic may then explain how the film's narrative symbolically reorients audiences to these values (Brinson, 1995; Frentz \& Rushing, 1978; Rushing \& Frentz, 1978). The central change agents in particular films, usually the films' main characters, frequently enact particular patterns of value reorientation by experiencing value changes themselves. Thus, the critic may identify the film's pattern of value change by observing the development of the film's main characters. Changes in characters that symbolically resolve conflicting social values function rhetorically by encouraging viewers to endorse a similar pattern of conflict resolution (Brinson 1995).

I adopt this method of analysis to explain how Ghosts of Mississippi's portrayal of district attorney Bobby DeLaughter, the film's main character, promoted a particular pattern referred to as a "dialectical transformation." Rushing and Frentz (1978) suggest that in the process of a character's dialectical transformation, "one set of values replaces the other as 
the underlying myth of social life" (p. 70). According to the Social Value Model of criticism, value reorientation cannot be enacted through depictions of competition between characters alone; agents of social change can be effective only if they appear to have experienced the new value psychologically (Rushing and Frentz, 1978, p. 70). Thus, films function rhetorically as models for social values transformations insofar as they depict the internal value transformation of the principle change agent. Ghosts of Mississippi enacted a shift from a racist value system to a more egalitarian one by depicting DeLaughter's transformation into a civil rights hero.

This article also augments the Social Value Model of criticism by pointing to the ways in which the confluence across the motion picture and journalistic coverage reinforced the social values transformation. Both news coverage and Ghosts of Mississippi portrayed Beckwith's conviction as a sign of changing race relations in the South by depicting the civil rights struggle as a conflict between good and evil individuals. Visual cues establishing this myth as historical truth constituted the narrative as a resource for remembering civil rights. Attention to press reports and to Ghosts of Mississippi as a social transformation myth sheds new light on the textual and intertextual construction of hegemonic memories in popular culture. By comparing news coverage and the film, I suggest that public memories are established through discrete and overlapping discourses that give social significance to the past; thus, scholarship attending to the hegemonic and ideological role of public memory might gain new insights by looking at confluence across texts about an historic event and to textual cues that establish the texts' relevance to social and political life.

\section{Casting Racist Evil Out of Mississippi in Journalistic Coverage of Beckwith's Trial}

As early as 1990, journalists acknowledged the significance of Beckwith's trial for public memory. According to one Washington Post reporter, Beckwith's "case has hung unresolved in the collective memory of a state where many attitudes about race have changed dramatically" (LaFraniere, 1990, p. A1). USA Today repeatedly noted that Evers's death was one of many murders of Blacks and civil rights activists that went unsolved (Mayfield, 1992a, p. 3A; Mayfield, 1992b, p. 3A; Mayfield \& Watson, 1992, p. 2A). Press coverage also explained how the mistrials in court cases against Beckwith occurred in the context of institutionalized racism in Mississippi's legal and justice system. During Beckwith's first trial, then-governor Ross Barnett stopped by the defense table to shake Beckwith's hand (Parker, 1991, p. A1). In addition, jury selection in the first trial was partially determined by potential jurors' answers to the question, “'Do you believe it's a crime for a white man to kill a nigger in Mississippi?'" (Booth, 1994b, p. A2; LaFraniere, 1990, p. A1). These reports situated Beckwith's acquittals as endemic to Mississippi's political life. As University of Mississippi history professor David Sansing told USA Today, Evers's death "'was not only perpetuated by an individual but condoned by a society at large'" (Mayfield, 1992b, p. 3A). Recounting the racial inequities that shaped the outcomes of the first two trials, the New York Times, Washington Post, and USA Today each acknowledged that the trial was not only about Beckwith; it was about "the Mississippi of the 1960s" (Booth, 1994b, p. A2; Mayfield, 1992b, p. 3A; Smothers, 1994a, p. A12). 


\section{Evil Racism Personified}

Journalistic coverage of Beckwith's trial characterized Evers's death as central to the history of Mississippi's violent and racist past. According to several reports, Evers's murder was one of the first killings of a well-known civil rights activist in Mississippi (Dreifus, 1994, p. 69; LaFraniere, 1990, p. A1; Mayfield, 1993, p. 38; Smothers, 1994a, p. A12). His was also one of the first deaths to galvanize the civil rights movement (Dreifus, 1994, p. 69, Parker, 1991, p. A1). One reporter quoted Assistant District Attorney Bobby DeLaughter in his closing statement: "This single, cowardly act of the person responsible for Medgar Evers's assassination has probably done more to hurt the state and the perception of Mississippi than any other single act I can think of" (LaFraniere, 1990, p. A1). By focusing on Beckwith as the primary cause of Mississippi's damaged reputation in the context of the states' civil rights injustices, reports positioned Beckwith as a metonymy for racist violence in Mississippi state history.

Reports also characterized Beckwith as the principal villain in the civil rights struggle. Press coverage characterized Beckwith as an "unregenerate hater" (Goodman, 1994, p. C14) and a staunch White supremacist whose views had not changed in the decades following Evers's death (Booth, 1994a, p. C1; "Evers defendant," 1992, p. A6; "Judge refuses," 1992, p. A4; Leavitt, 1992, p. 3A; "State set," 1992, p. A15). Early coverage of the impending trial described Beckwith's penchant for racialized violence in chilling detail. Reports noted that Beckwith had once called for a "confederate state of America as a white Christian republic" (Howard, 1990, p. 3A) and identified himself as being "on the white, right side of every issue" ("Slaying Suspect," 1994, p. A8; Smothers, 1990, p. A18). A neighbor living near Beckwith told the Washington Post that when Beckwith attended his mother's funeral, Beckwith declared, "'This is the way a funeral ought to be. No niggers and no Jews'" (LaFraniere, 1990, p. A1; Parker, 1991, p. A1). In an interview with reporters, Beckwith declared that he was "'willing to kill the evil in this country.'" When he complained about the cataract in his right eye, he added, "That's my shooting eye" (Howard, 1990, p. 3A). Other reports noted the prosecutor's evidence that Beckwith had endorsed "a great deal of shooting to protect our wives and children from bad niggers" (LaFraniere, 1990, p. A1); celebrated the assassination of integration supporter President John F. Kennedy (Smothers, 1994b, p. A10); and belonged to a White supremacist group, the Phinehas Priesthood, that asserted its "ordained duty to strike down those who are viewed as enemies of the pure white race" ("Man in Evers case," 1991, p. A18). These disturbing quotations positioned Beckwith's trial as a case against a sinister and dangerous racist.

Detailed coverage of the prosecution's case also framed Beckwith as the obvious suspect in Evers's death. On the first day of Beckwith's third trial, the New York Times asserted that "Mr. Beckwith's guilt, while never legally established, has long been a matter of moral certainty" (Smothers, 1994a, p. A12). The press recounted the testimonies of four courtroom witnesses who testified that Beckwith admitted to killing Evers years after the shooting. Daniel Prince, who rented an apartment from Beckwith in 1986 and 1987, recalled that Beckwith bragged, "II had a job to do and did it, and I didn't suffer any more than your wife if she was going to have a baby'" (Edmonds, 1994, p. 3A; Leavitt, 1994, p. 3A). Former $\mathrm{Ku}$ Klux Klan member Delmar Dennis reported that Beckwith made similar remarks at a 
Klan meeting, urging members, to "get in there and kill those enemies, including the president, from the top down" (Parker, 1991, p. A1; Smothers, 1994c, p. A10 ). Mary Ann Adams told jurors that she was introduced to Beckwith as "the man who killed Medgar Evers.'" When she refused to shake Beckwith's hand, Beckwith growled that he "'had not killed a man but a damn, chicken-stealing dog, and you know what you have to do when a dog has tasted blood'" (Booth, 1994d, p. A3; Edmonds, 1994, p. 3A; Leavitt, 1994, p. 3A; Smothers, 1994b, A10). Last to testify against Beckwith, former prison guard Mark Reilly testified that when Beckwith was serving prison time on an unrelated charge, he overheard Beckwith scream at a Black nurse's aide, "'If I could get rid of an uppity nigger like Medgar Evers, I'd have no problem getting rid of a no-account nigger like you'" (Booth, 1994e, p. A1; Edmonds, 1994, p. 3A; Smothers, 1994c, p. A10). Although reports extensively quoted witnesses who attested to Beckwith's admission of guilt, only the Washington Post vaguely recounted defense attorney's arguments that Beckwith was miles away from Evers's home on the night of Medgar Evers's shooting (Booth, 1994f, p. A9). By contrast, the New York Times coverage featured the prosecutor's cross-examination of the defense's key witnesses (Smothers, 1994d, p. A14).

In addition to framing Beckwith as Evers's known killer, several news reports characterized Beckwith as a dangerous beast. Early reports about the impending trial noted that Beckwith planned to fight prosecutors, "tooth, nail, and claw" (Nichols \& Howlett, 1992, p. A1; Smothers, 1990, p. A18). Prosecutors' remarks provided some of the most colorful denunciations of Beckwith. DeLaughter described Beckwith as a "rabid racist" (Booth, 1994c, p. A3; Smothers, 1994a, p. A12) and "back-shooting coward" (Booth, 1994e, p. A1; Smothers, 1994a, p. A12; Watson, 1994, p. 6A). In closing statements, DeLaughter compared Beckwith to a snake, telling jurors that Beckwith's "venom has come back to poison him" (Booth, 1994e, p. A1; Smothers, 1994e, p. 1.7). By characterizing Beckwith as a hatefilled man, as the obvious suspect in Evers's death, and in the image of a beast or serpent, an archetypal symbol of evil, newspaper reports cast Beckwith as the villain centrally responsible for Mississippi's damaged reputation.

\section{Casting Evil out of Mississippi}

Significantly, news reports also indicated that Beckwith was out of step with the South's current political climate. The New York Times coverage of reactions to Beckwith's arrest in his hometown outside of Chattanooga, Tennessee, is a case in point. According to this report, neighbors viewed Beckwith as "little more than a quiet eccentric ... who now is bringing a bad name to their town." Joseph Wagner, a local attorney quoted in the article described Beckwith as "a poor old fellow who's out of kilter, out of date." Wagner concluded, "You can't help but feel sorry for somebody like that. It's kind of pathetic" (Nichols, 1991, p. 3A). Later in the report, developer Tim Downey told reporter Nichols that residents resented implications that they shared Beckwith's racism. "If he's a white supremacist, he's the first I've ever met up here" (Nichols, 1991, p. 3A). In another report, Democratic Senator Hob Bryan told the Washington Post, "'Please, don't judge us all by that buffoon Byron De La Beckwith'"' (Booth, 1994h, p. B1). As these reports suggest, Beckwith represented a vestige of racial hatred in Mississippi's past. 
By framing Beckwith as a relic from the past, reports positioned the state's trial against Beckwith's as a sign of racial progress. USA Today reporters noted that for many Mississippians, the trial proved "to the world that the state is growing up" (Nichols \& Howlett, 1992, p. A1). Bennie Thompson, president of the Hinds County Board of Supervisors, told the New York Times that the trial was "a test of whether we have really made a change in our community" (Nichols, 1989, p. 3A). Likewise, the Washington Post reporter Parker (1991) described the trial as an opportunity "to demonstrate to the nation how this state, once a brutal bastion of white supremacy, has progressed" (p. A1). Beckwith's conviction stood as a final step of Mississippi's racial transformation. Several reports on Beckwith's indictment thus described the trial and expected prosecution as a "cleansing" for the state (Nichols \& Howlett, 1992, p. A1; Smothers, 1990, p. A18; Watson \& Edmonds, 1994, p. 3A). Because Beckwith stood in for racism in Mississippi history, his conviction indicated that racist filth had been eradicated.

Indeed, reports described Beckwith's conviction as the conclusion in the struggle for racial justice in the South. As Booth (1994g) reported for the Washington Post, "The guilty verdict was seen by many here as a sign that Mississippi ... had moved far beyond the state-supported racism that almost tore the country apart in the turbulent 1960s" (p. A1). Smothers (1994f) concluded that the verdict against Beckwith "closed an enduring chapter of civil rights violence and injustice in the South" (p. 1.1). Smothers's description of the verdict as the closing of a "chapter" is telling, for it illustrates how journalistic accounts framed Beckwith's trial as a narrative progression. According to reports, Beckwith's conviction concluded Mississippi's civil rights narrative with a happy ending. As National NAACP executive board chairman William Gibson told USA Today, "I think Mississippi has done itself proud" (Fields, 1994, p. 2A). Newspaper coverage of Beckwith's trial suggested that Beckwith was the embodiment of Mississippi's violent and racist past. Because Beckwith represented the evils of Mississippi's racist past, the climax to journalistic coverage of the trial called for Beckwith's expulsion. Beckwith's prosecution cleansed Mississippi of its racist legacy.

\section{Scapegoating Beckwith for Racial Violence}

By embodying Mississippi's racist past in Beckwith, press reports positioned Beckwith as a scapegoat for Mississippi's history of violence against African Americans and civil rights activists. Although Beckwith was responsible for the death of Evers, he was not solely responsible for the injustices done to African Americans and civil rights workers during the 1960s. As the history of the civil rights movement attests, Evers's death was part of a larger pattern of violence against Blacks and civil rights activists used to intimidate those who would challenge segregation and demoralize the movement (Anderson, 1995; Bloom, 1987). Burke (1969) describes the process of scapegoating as a ritual whereby blame for systemic social ills is transferred to individuals. He explains that "criminals either actual or imaginary may serve as scapegoats in a society that purifies itself by moral indignation in condemning them" (p. 406). Thus, the focus on Beckwith as a civil rights villain provided a symbolic curative for the broader social conditions that propelled lynchings and violence against Blacks during the movement's heyday. 
The symbolic cure produced by the news media's framing of Beckwith's conviction also displaced the realities of racial inequity and injustices that have persisted across the United States. The framing of Beckwith as the predominant cause for Mississippi's tarnished reputation belied the continued poverty and de facto segregation of Black and White neighborhoods in Jackson and elsewhere in the nation. In 1995, African Americans were three times more likely to live in poverty than Whites (Vobejda, 1995, p. A1). Additional instances of racially motivated violence against Blacks further indicate that racism endured at the time of Beckwith's conviction. According to the FBI, 4,710 racially motivated hate crime incidents occurred in 1997 in the United States ("FBI," 1999). During the early 1990s, as the case against Beckwith was growing, racial profiling was garnering news media attention as another incarnation of racism within America's justice system. News reports indicated that although African Americans represented 12\% of the population during the 1990s, they made up almost three-fourths of all routine traffic stops (Rogers, 2000, p. 94), composed half of the nation's prisoners (Thomas, 1995, p. A01), and were the most frequent victims of police shootings (Thomas, 1995, p. A01). In 1991, 33 of the 47 victims of Chicago police shootings were Black. Likewise, 152 Blacks in Indianapolis were shot by police, compared to 85 White victims (Thomas, 1995, p. A01). The image of three White police officers beating Rodney King in 1991 bore resemblances to images of police officers beating activists and Blacks in southern states during the Civil Rights Movement. Parallels between images of Blacks abused by the justice system in the 1960s and the 1990s indicated that state authorities had not yet accorded equal status to Blacks when Beckwith was convicted. By framing racial injustice as part of the past and as crusty and outdated as Beckwith himself, press attention to Beckwith's trial deflected attention from systematic racism that has persisted across the United States.

\section{The Social Values Transformation in Ghosts of Mississippi}

Popular depictions of Beckwith's trial as a sign of social transformation appeared beyond journalistic coverage. Rob Reiner's (1996) film Ghosts of Mississippi reinforces and extends news media frames of Beckwith's conviction as a sign of racial progress in Mississippi. Ghosts of Mississippi revolves around the valiant efforts of Hinds County Assistant District Attorney, Bobby DeLaughter, played by Alec Baldwin, to bring Beckwith to trial in the early 1990s. The motion picture uses the real names of people and events surrounding Beckwith's prosecution and corresponds closely to the press accounts of the state's efforts to hold Beckwith accountable for Evers's death. As the following sections of this paper explain, the film solidifies Beckwith's place in public memory as a scapegoat for Mississippi's violent past by portraying his prosecution through the narrative of DeLaughter's personal struggle to redeem Mississippi for future generations.

\section{Beckwith as a Civil Rights Villain}

Ghosts of Mississippi portrays Beckwith's conviction as the outcome of the struggle between an antiquated Mississippi past, embodied by Beckwith, and a progressive Mississippi, embodied by District Attorney Bobby DeLaughter. Echoing press reports, the film depicts Beckwith as a despicable character. Opening scenes establish Beckwith's role as the central 
villain. The film's first images show a middle-aged Beckwith, played by James Woods, kneeling in the bushes with a shotgun leveled at the Evers's driveway and then shooting Evers in the back as Evers walks toward his home. After the shots are fired, Myrlie and her children run out of the house toward Medgar. As Evers dies in Myrlie's lap, his children wail, “Daddy, Daddy, get up!” This scene corresponds closely with Myrlie Evers's testimony about her recollections of Medgar Evers's murder (Dreifus, 1994, p. 69). The film then cuts to scenes from the first two Beckwith trials, including one scene depicting Governor Ross Barnett shaking Beckwith's hand in the middle of Myrlie's testimony. The final image before the film shifts to Mississippi in the 1990s depicts Beckwith howling with glee when the judge announces a hung jury and Beckwith's release. These traumatic scenes position Beckwith as a callous murderer, willing to kill a man in front of his children. These initial scenes also depict the Mississippi court system as the primary obstacle to finding justice for Evers in 1964, providing the context for the film to portray Mississippi's transformation through its steadfast hero, District Attorney Bobby DeLaughter.

Beckwith's role as an unredeemable villain remains consistent throughout the film. In one scene, investigators view earlier documentary footage of Beckwith telling an interviewer, "I did not kill that man, but he sure is dead." With a sneer, Beckwith tells the camera, "And he ain't coming back." Toward the end of the film, Beckwith also confronts DeLaughter in the bathroom of the courthouse. After DeLaughter accuses Beckwith of shooting Evers as he would a deer, Beckwith, retorts, "A deer is a beautiful animal. . . I would never kill a deer. A nigger on the other hand, well, that's another matter entirely." Beckwith then adds, "You ain't never gonna get twelve people to convict me of killing a nigger in the state of Mississippi." These scenes underscore Beckwith's role as an archetypal villain as well as Mississippi's complicity in Beckwith's earlier mistrials. Indeed, film critic Howe (1996) concluded that Beckwith was "the villain of the year" (p. N44). As film critic Stack (1996) explained, Woods portrayed Beckwith as "dark, smirking evil" and as "a self-righteous hate monger publicly spewing venom at all minorities" (p. C3).

\section{The Triumph of a Civil Rights Hero}

In contrast to the film's depiction of Beckwith, Ghosts of Mississippi characterizes the central protagonist, District Attorney Bobby DeLaughter, as a benevolent family man who sought Beckwith's conviction for the sake of his children. According to the film, DeLaughter's role as a father influenced his decision to reopen the case against Beckwith. The attorney's commitment to bringing Beckwith to justice rests on his empathy with Evers's family. Before DeLaughter decides to reopen the case against Beckwith, he asks his colleague, "What kind of a man shoots another man in the back in front of his children?" Implicitly, only a degenerate would do such a thing; in the next scene DeLaughter convinces his superior, the state attorney general, to try Beckwith again. In an effort to prove his commitment to the case to Myrlie Evers, DeLaughter tells her, "No man has a right to take a man away from his children." The rest of the film depicts DeLaughter's efforts to attain evidence against Beckwith, gain the trust of Evers's widow, Myrlie, and convince a jury, which, in the film's final scene, finds Beckwith guilty. By highlighting DeLaughter's role as a family man, the film positions DeLaughter as Beckwith's antithesis. Notably, Beckwith's estranged son is never 
mentioned in the film. The absence of Beckwith's own family in the context of a film featuring DeLaughter's and Evers's families further distinguishes Beckwith as an inhumane villain far removed from the civil society that DeLaughter stands for. While Beckwith tore Evers's family apart, DeLaughter prosecutes Beckwith to honor the Evers's family ties.

Ghosts of Mississippi suggests that, at least for DeLaughter, family life and racial politics are inseparable. According to the film, DeLaughter initially resists requests to bring Beckwith to trial because he believes little evidence remained to prove Beckwith was Evers's murderer. In addition to the lack of physical evidence tying Beckwith to the crime, DeLaughter's wife and parents object to the state's interest in retrying the case. The film notes that DeLaughter's father-in-law, Russell Moore, who died before the case was revisited, was the judge who originally presided over the court proceedings in the 1964 trials that failed to convict Beckwith. The film also shows DeLaughter's mother making the racist statement that integration had "ruined [the] family's way of life." The conflict for DeLaughter is not only a struggle against the Mississippi legal system or against Beckwith; it was also a personal struggle. Thus, DeLaughter is caught at a crossroads, forced to choose between his convictions in furthering the cause of social justice and his ties to his racist parents and wife.

DeLaughter's decision to prosecute Beckwith transforms his own family. Because the racist ideology of DeLaughter's wife is fundamentally at odds with DeLaughter's ideals, his relationship with her dissolves. The problem, he tells her, is that she has not "changed," but he has. After he chooses to pursue Beckwith's conviction, DeLaughter builds a new family. As the case against Beckwith progresses, DeLaughter meets and eventually marries another woman, Peggy Lloyd, who applauds DeLaughter's efforts to bring Beckwith to trial. The importance of DeLaughter's personal transformation is highlighted after a scene in which DeLaughter receives a bomb threat at his house. When DeLaughter begins to doubt whether seeing the case to trial is worth the risk to his family's safety, Lloyd reminds him, "Someday your children are going to be able to tell their children that it was their daddy that put away Byron de la Beckwith." Lloyd thus reassures DeLaughter that prosecuting Beckwith is "the right thing" to do because Beckwith's conviction would symbolically redeem Mississippi for future generations.

By presenting Beckwith's prosecution as a struggle between competing characters, Ghosts of Mississippi crafts a "social values myth" in which the changes in the values of a society are symbolically represented through the struggles of characters featured in film (Rushing \& Frentz 1978, pp. 69-70). DeLaughter's personal transformation thus stands in metonymically for the broader social values transformation that prompted Beckwith's prosecution. The social significance of DeLaughter's personal transformation is depicted in two scenes highlighting his caretaking of his young daughter. In one of the film's early scenes, DeLaughter sings the song "Dixie" to his daughter to scare away a ghost that she imagines is haunting her room. This scene marks DeLaughter's own racism; since "Dixie" was the Confederate anthem during the Civil War, it connotes the South's efforts to resist challenges to its racist structures. The second time his daughter imagines the ghost in her room, she implores him to sing "Dixie." DeLaughter demurs: "Maybe Dixie's not the right song. Maybe that's why the ghost keeps coming back." DeLaughter proposes that his 
daughter sing her favorite song, "Old MacDonald." As the film's title, "Ghosts of Mississippi," suggests, DeLaughter's hesitation can be viewed as a metaphor for Southern politics; by continuing to support racism in the state, the ghosts of Civil Rights Past will continue to haunt Mississippi. Replacing "Dixie" with "Old MacDonald" exorcises the ghosts of racism in DeLaughter's own home. Concomitantly, Beckwith's conviction signals that the state of Mississippi has begun singing a racially progressive tune.

Ghosts of Mississippi casts DeLaughter as a mythic hero who struggles to save his children from a legacy of racism embodied by Beckwith, a man who held on to a tired and hate-filled value system. In closing statements, DeLaughter tells jurists that Evers was killed for "seeking equality for himself, his children, and his fellow men." He concludes that without justice for Evers, the wounds of Civil Rights Past "can never be healed." He implores the jury to convict Beckwith: "It is right, it is just, and Lord knows it is about time." When jurists announce Beckwith's guilt, cheers resonate throughout the court house and among the crowd outside. Those who object to Beckwith's conviction are not visible in the film's closing scene. This scene shows that Mississippi's civic identity has been redeemed; the evils of Mississippi's racist past have been overcome by a civil rights hero. By expunging Beckwith from society, DeLaughter transformed the collective memory of race relations for his family and for the state. DeLaughter not only argues for the state's social transformation, he embodies it. The narrative of DeLaughter's personal transformation thus extends newspaper coverage of Beckwith's trial by providing an image of Mississippi's future governed by the goals of racial equality and social justice.

\section{"Ghosts of Mississippi" as Historical Truth}

Press coverage of the film suggests that Ghosts of Mississippi was widely received as a source of public knowledge about racism in Mississippi. The film's director Rob Reiner suggested that he wanted Ghosts of Mississippi to play an educational role; during a press junket for the film's release he told reporters that people don't learn about the past from schoolbooks, "they get their history through movies" (Vargas, 1996, online archives). Mainstream film critics indicated that Reiner succeeded in establishing historical legitimacy with his film. Several critics described the film as a "true" or accurate representation of the White establishment's response to racism since 1964. Chicago Sun-Times critic Ebert (1996) stated that events leading to Beckwith's conviction were "remembered with fidelity" (p. NC33); Stack (1996) wrote that the film described events leading to Beckwith's conviction "with convincing details" (p. C3); and Ringel (1996) concluded that the film represented "the true story of the very different choices made by two white men in Mississippi" (p. 9P).

Such reviews were not without some critical caveats. Indeed, many reviewers, including those who characterized the film as a "true story," also noted that the film featured Whites as civil rights activists and ignored images of Blacks who fought for civil rights. Reviewers complained that the film focused "excessively" on White heroes (Maslin, 1996, p. C14) and revealed the enduring racism within the Hollywood film industry (Ringel, 1996, p. 9P; Sterritt, 1996, p. 12). Wickham (1996) concluded that "Hollywood's dirty little secret is that white filmmakers fear telling the story of a black historical figure or event from a black perspective" (p. 13A. See also Ashley, 1996, p. 1D; Bernard, 1996, p. 61; Clark, 1996, 13D). 
These reviewers addressed the racism inherent in films about civil rights that have excluded images of Black people. Although several reviewers mentioned racist exclusions in Ghosts of Mississippi, no reviewers writing for national papers provided alternative representations of Black history in their reviews of the motion picture. Nor did they discuss ongoing instances of brutality and injustice against Blacks that belied the "end of racism" narrative prevalent in journalism and film representations of Beckwith's trial.

Perhaps audiences and reviewers were influenced by intertextual and textual cues that asserted Ghosts of Mississippi's veracity to the past. For audiences who had followed news media coverage of Beckwith's trial, the film might have been immediately recognized as a source of historical information. The film built upon press accounts that framed Beckwith as an irredeemable villain. By sharing journalistic themes that scapegoated Beckwith for broader racial injustices, Ghosts of Mississippi encouraged audiences to understand the film as a dramatic, nonfiction narrative with important social implications. The movie solidified and extended that memory by positioning DeLaughter as Mississippi's emerging future.

\section{Public Memories That Displace the Present}

The social values transformation myth established by patterns across both Ghosts of Mississippi and journalistic coverage of Beckwith's trial told audiences that Beckwith represented the last vestige of racism that was extirpated from society through his conviction. Textual cues naturalized this memory by encouraging audiences to understand the social values transformation myth surrounding Beckwith's conviction as "a true story." By merging signifiers of realism with an intertextual social values narrative, popular media depictions of Beckwith's conviction constituted the social values transformation as a dominant public memory. For audiences unfamiliar with newspaper reports about Beckwith's 1994 prosecution, textual cues asserted the film's direct correspondence to historic events.

These visual cues functioned as signifiers of realism that attributed salience to Ghosts of Mississippi as a source of historical memory about the civil rights struggle. Captions and footage of events in the history of civil rights were signifiers of realism that framed the motion picture as the conclusion to the civil rights struggle. The film opened with the caption, "this is a true story," which told audiences to read the film as a source of historical information. In addition to this caption, the film's use of archival footage of events and individuals from the 1960s civil rights struggle linked Ghosts of Mississippi's narrative to the history of civil rights in the South. The film's opening scenes established the film within the context of the history of slavery and the civil rights movement in the United States. As credits rolled, a sequence of sepia-toned images projected archival images of events and figures pivotal to the history of the struggle for racial equality in the United States. The montage sequence provided images of violence against Black protesters (including police dogs attacking protesters with clubs and firehouses), of Blacks registering to vote, of Black leaders Malcolm X, Martin Luther King, and Frederick Douglass, and of sports figures Jackie Robinson and Muhammad Ali. These images were likely to have been familiar to audiences of journalistic media. Television journalism helped to galvanize widespread support for the civil rights movement in the United States by bringing images of movement activism and civil rights violence into people's living rooms (Torres, 2003). Documentary 
footage of events in civil rights history had been shown regularly during the decades preceding the movie's release. Brasell (2004) concludes that through their continued circulation in classrooms, documentaries, and commemorative institutes, media images of the civil rights struggle "continue to dominate our collective consciousness today" (p. 4). Thus, audiences were likely to have recognized images of pivotal figures and events in civil rights history from earlier televised broadcasts.

Reviewers suggested that these documentary images provided some of the most emotionally charged moments in the film. Maslin (1996) wrote that the film opened with a "rousing, majestic montage depicting landmarks of the civil rights struggle in America" (p. C14), and Hartl (1996) explained that the film's most "affecting moments" included a "telecast of President Kennedy's literate, poised endorsement of the movement's aims; the murder itself, which is handled with horrific straightforwardness; and Barnett's court appearance, which speaks volumes about what a Southern politician felt he could get away with in 1963" (p. F4). As these reviews suggest, Ghosts of Mississippi used visual representations of past civil rights events to position the social transformation narrative in the film as an extension of the 1960s civil rights movement. More precisely, documentary film techniques and footage from the civil rights movement framed Beckwith's conviction as the final conclusion to the civil rights struggle. As Ebert (1996) explained in his review of Ghosts of Mississippi, Beckwith's trial "close[d] a chapter in history" (p. 33NC). Portrayals of Beckwith's conviction indicate that social values myths are not exclusive to fictional films or to individual texts, but may constitute the broader frameworks in which we understand our place in history. By presenting Beckwith's conviction as the final chapter in civil rights in journalism and entertainment film, popular media positioned the social values transformation myth as an important narrative for understanding the relationship between civil rights in the past and race relations in the present.

Attention to ways in which Ghosts of Mississippi obscured the realities of racial injustice highlights the hegemonic function of this social transformation myth. The value change enacted by this myth did not transform the social order that currently maintains racial inequities. Understood in the context of ongoing racial struggle at the time of the film's release, Ghosts of Mississippi's narrative suggests that character transformations in film not only depict broader changes in social values; they also project as-yet unrealized social transformations into the popular imaginary. The social transformation depicted in the movie was mythic not only in Rushing and Frentz's (1978) use of the term ${ }^{3}$ but also because the film projected a reality that belied broader social experience. As a symbolic displacement of more contemporary instances of racial injustice and inequality, popular discourses about Beckwith's conviction helped to legitimate current economic, political, and social institutions that perpetuate racism.

The discrepancy between popular media depictions of Beckwith's conviction and the context of racial inequities during the mid-1990s also demonstrates how social values transformation myths may both appropriate and erase the struggles of historically oppressed groups from public memory. Film and journalism portrayals of Beckwith's prosecution appropriated the civil rights movement on behalf of Whites working within historically racist institutions. Paradoxically, the social values transformation myth enacted by these portrayals also erased the history of Southern antiracist struggles led by 
Black activists. Through this process of appropriation and erasure, this myth left racial struggle to the past.

By framing Beckwith as a metonymy for racial violence and DeLaughter as the central figure responsible for transforming society, Ghosts of Mississippi isolates the causes of racism in individuals, not in systematic structural inequities that persisted in the 1990s. The film's emphasis on DeLaughter as the civil rights hero who singlehandedly won a conviction against Beckwith thus frames the achievements of the civil rights movements as the actions of a single change agent. Attention to DeLaughter as a civil rights hero also obscures memories of activists such as Medgar Evers who fought against institutionalized racism during the 1960s.

As the only NAACP field secretary in Mississippi, Medgar Evers played a central role in the civil rights struggle by investigating the economic threats, beatings, and lynchings of Blacks who dared to support the NAACP or attempt to vote in the state (Nossiter, 1994/2002; Vollers, 1995). Evers also publicized the brutal murders of several Blacks in Mississippi, including the infamous lynching of 14-year-old Emmett Till in 1955 (Vollers, 1995). As the civil rights movement grew with grassroots support, other activists also advanced the cause of civil rights throughout the state. Among these activists were Bob Moses, who led the Student Nonviolent Coordinating Committee's (SNCC) voter registration drive between 1961 and 1964; students from the all-Black Tougaloo College and Jackson State College, who protested the segregated libraries in Jackson in 1961; James Meredith, the first Black person enrolled at the University of Mississippi in 1962; and Jack Slater, who organized month-long boycotts of Jackson's segregated businesses (Vollers, 1995).

Ghosts of Mississippi did not depict the climate of protest in Mississippi at the time of Medgar Evers's death and portrayed Evers solely in the scene of his murder. Thus, the film ignored Evers's legacy of efforts to resist violence perpetrated against Blacks in Mississippi and organize civil rights activists. Audiences with little knowledge about the history of the movement may conclude that the civil rights movement was fought by beneficent White authority figures, not by ordinary Black and White activists who struggled collectively for racial justice. The movie supplants memories of civil rights injustices with a narrative of White redemption in the present.

The state's climate of systemic violence and suppression is equally obscured in the film. The White establishment met activists' efforts with brutal repression. In 1956, Mississippi established the State Sovereignty Commission to hinder organizations that interfered with the state's segregation policies. This organization worked closely with the Citizens Councils designed to put economic pressure on Blacks to boycott the NAACP. Until 1961, when the grassroots civil rights movement reached Mississippi, Evers was the only individual to chronicle the commission's coercive campaign. Although Beckwith fired the shotgun that killed Evers, Evers's death served the White supremacist agenda. Indeed, the State Sovereignty Commission investigated potential jurors in Beckwith's second trial to eliminate civil rights sympathizers, thus prompting a mistrial.

White authorities also resisted other activists' efforts. In 1962, White students in Oxford, Mississippi, rioted when federal orders demanded that Black student James Meredith be allowed to attend the University of Mississippi. One year after Evers's death, local police participated in the murders of SNCC activists Andrew Goodman, Michael Schwerner, and 
James Chaney. As Bacciocco (1974) and Vollers (1995) point out, federal and state authorities did little to prosecute Whites who repressed activists with violence. By focusing on Beckwith as the single villain in the civil rights struggle, the film downplays the structural forces that perpetuated racial injustice throughout the South at the time of Evers's murder.

By creating a narrative vision of Mississippi's redemption, the social values transformation also relocated present realities of racial injustice and inequity to the past. The film's emphasis on DeLaughter's personal struggle positioned racial justice as an individual issue, not as a public good. Thus, Ghosts of Mississippi's narrative suggested that White families' growing support for civil rights constituted an end to racism. By personalizing the narrative of Beckwith's conviction, Ghosts of Mississippi deflected the contradiction between the myth that Beckwith's conviction left racism in the past and realities of ongoing racial inequities in the United States. In this regard, the film's personification of the civil rights struggle drained this social values transformation narrative of its public and political significance. Following news coverage of Beckwith's prosecution, the social values transformation myth in the film symbolically cleansed Civil Rights Past by suggesting that the values of racial equality had triumphed over values of racial hierarchy.

These conclusions indicate that texts that appear faithful to the historic record may also delimit historical understanding about contentious and traumatic events in the recent past. As scholars interested in popular communication and its implications for social justice, we must attend to the features of popular culture that encourage us to understand narratives as true or real, and recognize how these texts shut down spaces for critically thinking about the role of remembrance in the present. This process of understanding involves looking not only at the intertextual narratives that exclude critical voices in our nation's history of social struggle but also the textual signifiers that constitute these narratives as taken-forgranted or objective representations of the past.

These narratives have significance for the present. Public memories of Beckwith's conviction did not only close the book on past civil rights abuses; they also foreclosed spaces for critical analysis of contemporary race relations. Fused with signifiers of realism, the social values transformation myth provided limited space for competing and contrasting narratives about ongoing instances of racism and racially motivated violence in this country. Economic figures and more recent murders of Black men, such as the 1999 lynching of James Byrd, indicate that we can ill afford to leave public memories about racism with the ghosts from our past. Racism in the United States is still very much alive.

Acknowledgments - An earlier and condensed draft of this paper also appears in Rhetorical Agendas: Political, Ethical, Spiritual (Selected papers from the 2004 Rhetoric Society of America Conference) (2006). Ed. P. Bizzell. Mahwah, NJ: Lawrence Erlbaum Associates. The author wishes to thank Dana Cloud, Lisa Foster, and Emmett Winn for comments on earlier drafts of this paper. The author also gives special thanks to the anonymous reviewers and to the editor for their valuable remarks and suggestions. 


\section{Notes}

[1] The Southern Poverty Law Center identified 15 of these cases in Mississippi at the time of Beckwith's conviction including the 1964 murders of civil rights activists James Chaney, Andrew Goodman, and Michael Schwerner near Philadelphia, Mississippi; the 1966 murder of civil rights activist Vernon Dahmer in Hattiesburg; and the 1964 murders of Henry Hezekiak Lee and Charles Eddie Moore near Meadville (Nossiter, 1994, p. B18).

[2] Men recently convicted for civil rights murders include Sam Bowers on August 21, 1998, for the 1966 murder of Vernon Dahmer (Sullivan, 1998, p. A1); Thomas Blanton on May 1, 2001, for the 1963 bombing of the 16th St. Baptist Church in Birmingham, Alabama, that killed four Black girls (Copeland, 2001, p. 2A); Bobby Frank Cherry on May 22, 2002, also for the 1963 bombing of the 16th St. Baptist Church (Bragg, 2002, p. A2); and Ernest Avant on February 28, 2003, for the 1966 murder of Ben Chester White (Hart, 2004, p. 23).

[3] Rushing and Frentz (1978) define myth as "society's collectivity of persistent values, handed down from generation to generation, that help to make the world understandable, support the social order, and educate the society's young" (p. 67).

\section{References}

“Academy Awards nominees." (1997, March 24). USA Today, p. 3D.

Anderson, T. (1995). The movement and the sixties. Oxford and New York: Oxford University Press.

Ashley, B. (1996, December 19). Thumbs down [Review of the motion picture Ghosts of Mississippi]. USA Today, p. 1D.

Bacciocco, E. J., Jr. (1974). The New Left in America: Reform to revolution, 1956-1970. Stanford, CA: Hoover Institution.

Bernard, J. (1996, December 20). Mississippi: Old man (up the river): Equal parts history and mystery, with a dark, scary Woods as Evers's assassin [Review of the motion picture Ghosts of Mississippi]. Daily News, p. 61.

Bloom, J. M. (1987). Class, race, and the Civil Rights Movement. Bloomington, IN: Indiana University Press.

Bodnar, J. (1992). Remaking America: Public memory, commemoration, and patriotism in the twentieth century. Princeton, NJ: Princeton University Press.

Booth, W. (1994a, January 19). A shot heard across three decades: In a Mississippi courtroom, the man accused of killing a civil rights pioneer stands trial once more. The Washington Post, p. C1.

Booth, W. (1994b, January 21). Bias and race still pertinent as 3rd Beckwith trial opens. The Washington Post, p. A2.

Booth, W. (1994c, January 28). Widow of Medgar Evers tells of 'horrible blast': Testimony highlights first day of Mississippi retrial of man accused in 1963 slaying. The Washington Post, p. A3.

Booth, W. (1994d, February 1). Beckwith boasted of killing, jury told: Witnesses recall words of defiant accused in 1963 Evers slaying. The Washington Post, p. A3.

Booth, W. (1994e, February 2). Surprise testimony finishes prosecution's Beckwith case. The Washington Post, p. A1.

Booth, W. (1994f, February 3). Ex-police officer repeats 1963 alibi that distances Beckwith from slaying. The Washington Post, p. A9. 
Booth, W. (1994g, February 6). Beckwith convicted of murdering Evers: White supremacist gets life in '63 shooting. The Washington Post, p. A1.

Booth, W. (1994h, February 11). Jackson, Miss.: The city time remembers: Has it really changed since the murder of Medgar Evers? The Washington Post, p. B1.

Bragg, R. (2002, May 22). 38 years later, last of suspects is convicted in church bombing. New York Times, p. A2.

Brasell, B. (2004). From evidentiary presentation to artful re-presentation: Media images, civil rights documentaries, and the audiovisual writing to history. Journal of Film and Video, 56, 3-17.

Brinson, S. (1995). The myth of white superiority in Mississippi Burning. The Southern Communication Journal, 60, 211-221.

Browne, S. H. (1999). Remembering Crispus Attucks: Race, rhetoric, and the politics of commemoration. Quarterly Journal of Speech, 85, 169-187.

Burke, K. (1969). A grammar of motives. Berkeley, CA: U of California Press.

Clark, M. (1996, December 20). Woods gives Ghosts its only substance [Review of the motion picture Ghosts of Mississippi]. USA Today, p. 13D.

Copeland, L. (2001, May 1). Former Klansman guilty in '63 church bombing. USA Today, p. 2A.

Dionisopoulos, G. \& Goldzwig, S. (1992). “The meaning of Vietnam”: Political rhetoric as revisionist cultural history. Quarterly Journal of Speech, 78, 61-79.

Dreifus, C. (1994, November 27). The widow gets her verdict. New York Times, p. 69.

Eagleton, T. (1991). Ideology: An introduction. London and New York: Verso Press.

Ebert, R. (1996, December 20). White wash: Mississippi focuses on wrong story [Review of the motion picture Ghosts of Mississippi]. Chicago Sun-Times, p. 33NC.

Edmonds, P. (1994, February 2). Beckwith's been bragging for 30 years, witnesses say. USA Today, p. 3A.

Ehrenhaus, P. (1989). Commemorating the unwon war: On not remembering Vietnam. Journal of Communication, 39, 96-107.

Ehrenhaus, P. (2001). Why we fought: Holocaust Memory in Spielberg's Saving Private Ryan. Critical Studies in Media Communication, 18, 3211-337.

“Evers defendant testifies." (1992, August 4). The Washington Post, p. A6.

"FBI: Race still most frequent motive for hate crimes." (1999, November 18). CNN.com.

Fields, G. (1994, February 3). A boost for Beckwith's claims: Defendant was 90 miles away, ex-officer says. USA Today, p. 2A.

Frentz, T. S. \& Rushing, J. H. (1978). The rhetoric of "Rocky": Part Two. Western Journal of Communication, 42, 231-240.

Gitlin, T. (1980). The whole world is watching: Mass media in the making and the unmaking of the New Left. Berkeley: University of California Press.

Goodman, W. (1994, July 11). TV review: Medgar Evers and his tragic end. New York Times, p. C14.

Gramsci, A. (1977, 1971). Selections from the prison notebooks (Q. Hoare \& G. N. Smith, Trans.). New York: International Publishers.

Hall, S., Critcher, C., Jefferson, T., Clarke, J., \& Roberts, B. (1978). Policing the crisis: Mugging, the state, and law and order. New York: Holmes and Meier.

Hart, A. (2004, April 22). National briefing: South: Louisiana: Conviction stands in sharecropper case. New York Times, p. 23.

Hartl, J. (1996, December 20). Ghosts leaves an incomplete feeling [Review of the motion picture Ghosts of Mississippi]. The Seattle Times, p. F4. 
Hasian, M. (2001). Nostalgic longings, memories of the "Good War," and cinematic representations in Saving Private Ryan. Critical Studies in Media Communication, 18, 338-358.

Hasian, M. \& Carlson, C. (2000). Revisionism and collective memory: The struggle for meaning in the Amistad Affair. Communication Monographs, 67, 42-55.

Howard, L. (1990, December 18). Figure in Evers's case battles "evil." USA Today, p. 3A.

Howe, D. (1996, December 20). Haunting ghosts. The Washington Post, p. N44.

"Judge refuses to dismiss Beckwith murder charge." (1992, August 5). The Washington Post, p. A4.

Kammen, M. (1991). Mystic chords of memory: The transformation of tradition in American culture. New York: Knopf.

Leavitt, P. (1992, August 4). Evers case. USA Today, p. 3A.

Leavitt, P. (1994, February 1). Witnesses recall Beckwith's boasts. USA Today, p. 3A.

LaFraniere, S. (1990, December 19). Murder charge filed in Evers case: Supremacist faces third trial in 1963 slaying of NAACP official. The Washington Post, p. A1.

Madison, K. (1999). Legitimation crisis and containment: The "anti-racist-white-hero" film. Critical Studies in Mass Communication, 16, 399-416.

"Man in Evers case tied to hate group." (1991, October 30). New York Times, p. A18.

Maslin, J. (1996, December 20). Film review: For a true story, dipping into the classics. [Review of the motion picture Ghosts of Mississippi] New York Times, p. C14.

Mayfield, M. (1992a, October 16). Miss. court takes up Evers case. USA Today, p. 3A.

Mayfield, M. (1992b, December 17). Court OKs 3rd trial in Evers's death. USA Today, p. 3A.

Mayfield, M. (1993, June 11). Activists gather to mourn Evers, civil rights hero. USA Today, p. 2 A.

Mayfield, M. \& Watson, T. (1992, September 28). Guilt, innocence blur with passage of time. USA Today, p. 2A.

“Mississippi." (1990, December 26). USA Today, p. 6A.

Nichols, B. (1989, December 11). Grand jury gets Evers case: Probe will examine '63 rights killing. USA Today, p. 3A.

Nichols, B. (1991, January 9). “Beckwith: Who is he?" Few aware of neighbor's link to Evers slaying. USA Today, p. 3A.

Nichols, B. \& Howlett, D. (1992, December 19). 'Justice is waking up': Miss. tries again to close Evers murder case: Beckwith to fight 'tooth, nail and claw.' USA Today, p. A1.

Nossiter, A. (2002). Of long memory: Mississippi and the murder of Medgar Evers. Cambridge, MA: DeCapo Press. (Original work published in 1994)

Owens, A. S. (2002). Memory, war, and American identity: Saving Private Ryan as cinematic jeremiad. Critical Studies in Media Communication, 19, 249-282.

Parker, L. (1991, February 6). Reliving the Evers death: Mississippi haunted by '63 murder of black activist. The Washington Post, p. A1.

Reiner, R. (Director). (1996). Ghosts of Mississippi [Motion picture]. United States: Castle Rock Entertainment and Columbia Pictures.

Ringel, E. (1996, December 20). Review: Ghosts of Mississippi [Review of the motion picture Ghosts of Mississippi]. The Atlanta Journal and Constitution, p. 09P.

Rogers, E. (2000). Fear of driving: Congress considers study of racial profiling in police traffic stops. ABA Journal, 86, 94. Retrieved January 21, 2001, from Lexis-Nexis database.

Rushing, J. H. \& Frentz, T. S. (1978). The rhetoric of "Rocky": A social value model of criticism. Western Journal of Communication, 41, 63-72. 
"Slaying suspect confident." (1994, January 11). The Washington Post, p. A8.

Smothers, R. (1990, December 19). Supremacist is charged for 3d time with killing Medgar Evers in 1963. New York Times, p. A18.

Smothers, R. (1994a, January 28). 30 years later, 3d trial begins in Evers killing. New York Times, p. A12.

Smothers, R. (1994b, February 1). Defendant in Evers slaying keeps racial views private. New York Times, P. A10.

Smothers, R. (1994c, February 2). Witnesses recall boasts on '63 killing. New York Times, P. A10.

Smothers, R. (1994d, February 3). Defense follows familiar course in Evers slaying. New York Times, p. A14.

Smothers, R. (1994e, February 4). '63 Murder case goes to the jury. The New York Times, p. 1.7.

Smothers, R. (1994f, February 6). White supremacist is convicted of slaying rights leader in '63. The New York Times. p. 1.1.

Stack, P. (1996, December 20). Mississippi a burning drama on Evers murder: Goldberg, Woods superb in story spanning 30 years [Review of the motion picture Ghosts of Mississippi]. San Francisco Chronicle, p. C3.

“State set for trial in killing of Medgar Evers." (1992, August 5). New York Times, p. A15.

Sterritt, D. (1996, December 20). Chilling civil-rights story plays out on big screen [Review of the motion picture Ghosts of Mississippi]. The Christian Science Monitor, p. 12.

Sturken, M. (1997). Tangled memories: The Vietnam War, the AIDS Epidemic, and the Politics of Remembering. Berkeley: University of California Press.

Sullivan, B. (1998, August 21). Bowers convicted of killing Dahmer/Ex-Klan leader gets life term in '66 murder. The Commercial Appeal, p. A1.

Thomas, P. (1995, December 6). Police brutality: An issue rekindled. The Washington Post, p. A1.

Torres (2003). Black, white, and in color: Television and black civil rights. Princeton, NJ: Princeton University Press.

Tucker, C. (2005, June 27). At last, justice is served in Mississippi. The Baltimore Sun, p. 9A.

Vargas, E. (1996, August 20). Good Morning America [Untitled transcript]. New York: American Broadcasting Companies, Inc. Retrieved March 15, 2004, from Lexus-Nexus news database, transcript \#2658-1.

Vobejda, B. (1995, October 6). U.S. reports decline in number of poor: Decrease is first since 1989. The Washington Post, p. A1.

Vollers, M. (1995). Ghosts of Mississippi: The murder of Medgar Evers, the trials of Byron de la Beckwith, and the Haunting of the New South. Boston, MA: Little Brown \& Co.

Watkins, C. (2001). Framing protest: News media frames of the Million Man March. Critical Studies in Media Communication, 18, 83-101.

Watson, T. (1994, January 28). The day "Daddy" died: Evers's wife describes the terror of '63. USA Today, p. 6A.

Watson, T. \& Edmonds, P. (1994, January 17). 3rd trial for white supremacist accused of Evers's '63 slaying. USA Today, p. 3A.

Wickham, D. (1996, December 24). Black hero missing in movie: Hollywood leaves Medgar Evers on sidelines of his own story. USA Today, p. 13A.

Zelizer, B. (1995). Reading the past against the grain: The shape of memory studies. Critical Studies in Mass Communication, 12, 214-240. 